\title{
Engineered Recombinant Single-Chain Fragment Variable Antibody for Immunosensors
}

\author{
Zhihong Shen ${ }^{\dagger}$, Raymond L. Mernaugh ${ }^{\ddagger}$, Heping Yan ${ }^{\ddagger}$, Lei Yu ${ }^{\dagger}$, Ying Zhang ${ }^{\ddagger}$, and Xiangqun \\ Zeng ${ }^{\star}, \dagger$ \\ $\dagger$ Department of Chemistry, Oakland University, Rochester, Michigan 48309 \\ $\$$ Department of Biochemistry, School of Medicine, Vanderbilt University, Nashville, Tennessee 37232
}

\begin{abstract}
A recombinant single-chain fragment variable ( $\mathrm{scFv}$ ) antibody (designated A10B) was engineered to contain two histidines within the linker peptide used to join the scFv heavy and light chains. A piezoimmunosensor using the $\mathrm{scFv}$ was successfully developed. A10B scFv bound to the gold piezoimmunosensor surface were correctly oriented, retained antigen-binding activity, and coupled at high surface concentration. These results, and results obtained from an earlier study using an $\mathrm{scFv}$ containing a linker cysteine, suggest that the location on the linker sequence in which the amino acids were incorporated was well tolerated by the scFv and did not interfere with $\mathrm{scFv}$ antigen-binding activity. The scFv-modified QCM sensor was thoroughly characterized and used to specifically detect antigen in crude serum sample and had a sensitivity of $2.3 \pm 0.15 \mathrm{nM}(n=4)$ with a linear range over $2.3 \times 10^{-9}-3.3 \times 10^{-8} \mathrm{M}$. The piezoimmunosensor was also used to study the kinetics and thermodynamics of antigen/scFv antibody binding.
\end{abstract}

\begin{abstract}
Affinity-based biosensors are analytical devices that use antibodies, DNA, or receptor proteins interfaced to signal transducers to measure binding events. ${ }^{1}$ Biosensors that utilize antibodies as recognition elements are often called immunosensors. A large number of different highaffinity, antigen-specific antibodies can be readily obtained through commercial sources. Therefore, most of the reported affinity-based biosensors are immunosensors. Immunosensors often employ absorbance, fluorescence, amperometric, or radiochemical transduction mechanisms, requiring labeled receptors to report, indirectly, the presence of the analytes. The use of labeled receptors, however, generally results in additional preparative steps and higher overall costs. In the past decades, several techniques have been developed that allow for the direct detection of analytes in immunoassays. These immunoassays require the immobilization of antibody on a solid support and measure a change in potential difference, current, resistance, mass, or optical properties. ${ }^{2}$ Typically, antibodies are immobilized passively (e.g., via hydrophobic interactions) or attached covalently (e.g., via antibody-free amines or carboxyl groups) to solid supports. ${ }^{3}$ Under these conditions, antibody orientation and antigen-binding activity can be lost. The antigen-binding activity of an antibody can be retained if antibodies can be oriented upon coupling through the use of protein A (for protein A-binding IgG antibodies) or coupling (e.g., anti-IgG Fc-specific) antibodies previously immobilized onto the solid support. However, these reagents can also bind other irrelevant molecules and lead to assay background problems. Other methods described can be used to immobilize antibodies on a solid surface to improve antibody orientation; for example, antibodies can be immobilized
\end{abstract}

*To whom correspondence should be addressed. E-mail: zeng@oakland.edu. Fax: 248-370-2321.

SUPPORTING INFORMATION AVAILABLE Additional information as noted in text. This material is available free of charge via the Internet at http://pubs.acs.org. 
via antibody-oxidized glycochains or reduced disulfide bonds. ${ }^{4,5}$ Even though significant progress has been made, it is still difficult to immobilize sufficient amounts of properly oriented antibody on immunosensors using existing methodology.

An IgG antibody consists two heavy ( $\sim 55 \mathrm{kDa})$ and two light ( $\sim 25 \mathrm{kDa})$ polypeptide chains joined by disulfide bonds. The antigen-binding sites of an antibody are known as the paratopes. There are two paratopes on each IgG antibody. A paratope is composed of a pair of each heavyand light-chain fragment. The amino acid sequences present in and around the paratope vary from one antigen-specific antibody to another. Together, these two antibody variable regions make up $\sim 34 \%$ of the total antibody mass. The remainder of the antibody, the antibody constant region, does not typically contribute to the antigen-binding activity of an antibody.

Recombinant single-chain fragment variables $(\mathrm{scFv})$ are small heterodimers comprising the antibody variable heavy $\left(\mathrm{V}_{\mathrm{H}}\right)$ and light $\left(\mathrm{V}_{\mathrm{L}}\right)$ pairs. A peptide linker is used to stabilize the $\mathrm{V}_{\mathrm{H}^{-}} \mathrm{V}_{\mathrm{L}}$ pairs. ${ }^{6,7}$ Recombinant scFv antibodies represent one of the smallest functional $\mathrm{V}_{\mathrm{H}^{-}}$ $\mathrm{V}_{\mathrm{L}}$ domains of an antibody necessary for antigen-binding activity. ${ }^{8}$ Since $\mathrm{scFv}$ antibodies are small, they can be easily expressed as unique entities or as fusion proteins in bacteria.

Recombinant antibodies and their fragments now represent over $30 \%$ of all biological proteins undergoing clinical trials. ${ }^{9}$ Despite the apparent benefits of recombinant antibody technologies, their applications in fields, such as immunosensors, are not well explored. Recently, we compared the performance of an IgG monoclonal antibody, the monoclonal $\operatorname{IgG}$ $\mathrm{Fab}$ and the scFv fragments of the $\mathrm{IgG}$ monoclonal antibody (engineered to contain a linker bearing a single cysteine) for use in piezoimmunosensors to detect an antigen in a complex biological serum sample. ${ }^{10}$ The scFv-based immunosensors displayed greater assay sensitivity and exhibited less nonspecific activity than intact monoclonal IgG and Fab fragment-based immunosensors.

The peptide linker connecting $\mathrm{scFv} \mathrm{V}_{\mathrm{H}}$ and $\mathrm{V}_{\mathrm{L}}$ domains connects the carboxyl terminus of one variable region domain to the amino terminus of the other variable domain without compromising the fidelity of the $\mathrm{V}_{\mathrm{H}}-\mathrm{V}_{\mathrm{L}}$ paring and antigen-binding sites. Peptide linkers can vary from 10 to 25 amino acids in length and are typically, but not always, composed of hydrophilic amino acids such as glycine $(\mathrm{G})$ and serine $(\mathrm{S})$. Peptide linkers of shorter lengths ( $0-4$ amino acids) have also been used. However, scFvs bearing shorter linkers can form multimers. Generally, the (GGGGS) 3 peptide is used as an scFv peptide linker. In a previous report, we have demonstrated that $\mathrm{scFv}$ in which a cysteine $(\mathrm{C})$ amino acid is incorporated into the (GGGGS) ${ }_{3}$ peptide linker can self-assemble and be immobilized with correct orientation and high surface concentration on gold. ${ }^{10}$ The recombinant $\mathrm{scFv}$ immunosensor demonstrated significant advantages over those of traditional polyclonal and monoclonal antibodies with improved assay sensitivity and specificity. ${ }^{10}$ However, when cysteines are incorporated into some recombinant $\mathrm{scFv}$ antibodies, $\mathrm{scFv}$ antigen-binding activity can be disrupted through inter-scFv disulfide bond formation and $\mathrm{scFv}$ aggregation, or $\mathrm{scFv}$ bacterial protein expression can be substantially reduced.

Techniques that allow the oriented and reversible immobilization of proteins on gold surfaces via hexahistidine extension has been reported. ${ }^{11-16}$ It was recognized that the immobilization of His-rich proteins or polypeptides is through the strong interaction of histidine and the gold surface either through the lone pair electron on nitrogen or through the $\pi$-orbital of aromatic immidazolium ring. ${ }^{17}$ Histidine tags (His-tags; e.g., (His) $\left.)_{n}, n=4-6\right)$ ) have been incorporated into many recombinant proteins and $\mathrm{scFv}$ antibodies. The His-tags are located on the amino or carboxyl terminus of the proteins or scFvs and are used for purification. Typically, His-tags located on the $\mathrm{scFv}$ carboxyl terminus do not interfere with scFv-binding activity. However, each histidine in His-tags could potentially interact with the gold electrode; this multiplexing capability can reduce the flexibility of the protein and complicate its adsorption on gold electrode. To take advantage of scFvs for use in immunosensor-based assays and His-gold 
interaction, a linker incorporating two histidines separated by two glycines as a spacer (i.e., SHGGHGGGGSGGGGS) was designed. Since a suitable location in the scFv linker had already been determined in which to place a cysteine for $\mathrm{scFv}$ coupling to gold immunosensors, a similar location on the linker was also chosen to incorporate two histidines. This design apparently gave the peptide linker the flexibility needed to optimally align histidines for gold binding and correct $\mathrm{scFv}$ orientation. In addition, the GGH motif also bound $\mathrm{Cu}^{2+}$ cations in solution and formed a stable complex. So the GGH motif can be used as a surface indicator to understand the $\mathrm{scFv}$ protein adsorption processes. ${ }^{18}$

The A10B scFv was used as part of a model system to determine whether the designed SHGGHGGGGSGGGGS scFv linker could be used to couple scFv to gold immunosensor surfaces. The A10B scFv is a recombinant antibody that was generated using the $\mathrm{A} 10 \mathrm{~B}$ hybridoma cell line as a source of genetic information. A10B scFv display an E-tag peptide that is recognized by a peroxidase-conjugated anti-E tag monoclonal antibody (Amersham Catalog No. 27941301). The presence of E-tagged scFv is visualized using the peroxidaseconjugated monoclonal antibody and peroxidase colorimetric substrate. The A10B hybridoma monoclonal IgG and $\mathrm{scFv}$ recombinant antibodies specifically bind rabbit IgG. This model system has several distinct advantages. The $\mathrm{A} 10 \mathrm{~B}$ antibodies are readily obtained, and the $\mathrm{scFv}$ are cloned and amenable to genetic modification. The antigen (rabbit $\operatorname{IgG}$ ) is inexpensive, can be readily purified, conjugated to biotin, dyes, enzymes, and beads, and used in a variety of applications to develop and troubleshoot a new assay platform, such as a piezoimmunosensor. The A10B monoclonal/recombinant antibodies and rabbit IgG are stable and can be stored frozen or unfrozen for months or even years with little or no loss of activity. Therefore, reagent instability was essentially eliminated as a source of variation during this feasibility study. A number of traditional immunoassays (e.g., ELISA) can be used to monitor relative concentration and biological activity of reagents present on immunosensors after immobilization.

Our study demonstrates that $\mathrm{A} 10 \mathrm{~B} \mathrm{scFv}$, engineered to contain two linker-bearing histidines, bound to gold surfaces. The scFv were correctly oriented and coupled at high surface concentration in a biologically active form on the gold surface of an immunosensor. These results, and results obtained from an earlier study using an $\mathrm{scFv}$ containing a linker cysteine, suggest that the location on the linker sequence in which the amino acids were incorporated was well tolerated by the $\mathrm{scFv}$ and did not interfere with antigen-binding activity. These results also demonstrate that histidine, as well as cysteine, can be used to couple an scFv to a gold substrate. The option to use either cysteine or histidine is important in that some scFv can lose antigen-binding activity or can be poorly expressed in bacterial cultures if one, but not the other, amino acid is used to produce scFv for use on gold-based immunosensors.

\section{EXPERIMENTAL SECTION}

\section{Chemicals and Materials}

Bovine serum albumin (BSA; Catalog No. A-4503), rabbit IgG (Catalog No. I-5006), goat antirabbit IgG (Catalog No. R-2004), and goat anti-human IgG (Catalog No. I-3382) were purchased from Sigma Inc. Fab fragment of rabbit anti-mouse IgG (Catalog No. 315-007-003) and Fab fragment of goat anti-rabbit IgG (Catalog No. 111-007003) were purchased from Jackson Immunolabs. The peroxidase conjugated anti-E tag monoclonal antibody (Catalog No. 27941301) was obtained from Amersham. Peptides SHGGHGGGGSGGGGS and $\left(\right.$ GGGGS) ${ }_{3}$ (abbreviated as peptide-H and peptide-G, respectively, hereafter) were purchased from Openbiosystems, Inc. Phosphate-buffered saline (PBS), pH 7.2 (Gibco BRL No.

20012-027), fetal bovine serum (FBS) (Gibco BRL No. 16000-044) and all other chemicals (Aldrich) are reagent grade and used as received. 


\section{A10B scFv Genetic Engineering}

An A10B hybridoma cell line was used as the source of genetic information for production of $\mathrm{scFv}$. This cell line produces a monoclonal IgG1 antibody that binds specifically to the constant region $\left(\mathrm{C}_{\mathrm{H}} 1\right)$ of rabbit IgG. Synthetic oligonucleotides encoding for the

GGGGSGGGGSGGGGS and SHGGHGGGGSGGGGS amino acid linker sequences were used to join the A10B $V_{H}$ and $V_{L}$ DNA sequences to create, respectively, the A10B scFv-Rs construct and $\mathrm{A} 10 \mathrm{~B}$ scFv-His construct. Full amino acids and nucleotide sequence was shown in Figure S1 (Supporting Information). The scFv recombinant antibodies were produced and purified according to a previously published protocol using an Amersham RPAS purification. 19

\section{ScFv Western Blot}

Anti-E tag monoclonal antibody affinity purified anti-rabbit IgG A10B-Rs (with GGGGSGGGGSGGGGS linker), A10B-His (with SHGGHGGGGSGGGGS linker), A10BCys (with CGGGSGGGGSGGGGS linker), and anti-CYP1B1 I20 (with GGGGSGGGGSGGGGS linker) scFvs were boiled in SDS/mercaptoethanol gel loading buffer. A $10 \%$ polyacrylamide gel was loaded with boiled-denatured $\mathrm{scFv}(7.5 \mathrm{ng} / \mathrm{lane})$ and electrophoresed. E-tagged $\mathrm{scFv}$ were transferred to a nitrocellulose membrane. Membrane blots were blocked with PBS containing $0.1 \%$ Tween 20 and 3\% nonfat dry milk and then probed with peroxidase-conjugated anti-E tag monoclonal antibody diluted 1:10 000 in blocking buffer. Blots were washed with PBS containing 0.1\% Tween 20 and then were exposed to a chemiluminescent substrate (Pierce Catalog No. 34080) and film.

\section{ScFv Enzyme-Linked Immunosorption Assay (ELISA)}

Wells of a 384-well microtiter plate (Nunc Catalog No. 242757) were coated with $30 \mu \mathrm{L} /$ well purified rabbit IgG, BSA, or the P450 enzyme CYP1B1 (prepared by Dr. Fritz Parl at Vanderbilt University) diluted in PBS to $10 \mu \mathrm{g} / \mathrm{mL}$, washed, and then blocked with PBS containing $0.1 \%$ Tween 20 . Anti-E tag monoclonal antibody affinity purified scFvs were diluted in PBS containing $0.1 \%$ Tween 20 , and $30 \mu \mathrm{L}$ of diluted scFv was applied to each antigen-coated well. Wells were washed with PBS containing $0.1 \%$ Tween 20 and then probed with peroxidase-conjugated anti-E tag monoclonal antibody diluted 1:5000 in PBS containing $0.1 \%$ Tween 20. After washing, wells were developed using hydrogen peroxide and 2,2' azinobis(3-ethylbenzthiasolinesulfonic acid).

\section{Immobilization Procedure}

The Au quartz crystals used in this study were AT-cut, $10-\mathrm{MHz}$, nonpolished, and coated with gold film of 1000- $\AA$ thickness on both sides. (Provided by International Crystal Co.). The geometric area of the coating area is $\sim 0.23 \mathrm{~cm}^{2}$. The quartz crystal was mounted in a custommade Kel-F cell sealed with two Viton O-rings. The quartz crystal was cleaned with concentrated nitric and sulfuric acid mixture, biograde water (i.e., $2-\mu \mathrm{m}$ prefiltered 18-M $\Omega$ deionized water with UV radiation), and ethanol in series for three times to remove impurities, and dried with nitrogen. Only one side of the quartz crystal was immersed in a solution of $\mathrm{scFv}-\mathrm{His}(0.3 \mathrm{mg} / \mathrm{mL})$ in PBS buffer at $4{ }^{\circ} \mathrm{C}$ for $15-22 \mathrm{~h}$. After incubation, the electrode surface was washed with PBS buffer and biograde water to remove unbound scFv-His. To minimize nonspecific adsorption, the unoccupied active gold surface on the scFv-His modified electrode was blocked with PBS containing 0.1\% BSA for 30 min. After blocking, the cell was further washed by PBS buffer and biograde water to remove any unbound BSA. The A10B monoclonal and recombinant $\mathrm{scFv}$ antibodies were immobilized using similar procedures. 


\section{Electrochemical Characterization}

Cyclic voltammetry (CV) and electrochemical impedance spectroscopy (EIS) were performed with a Parstat 2263 Advanced Electrochemical System (Princeton Applied Research). For all the experiments, bare or modified gold electrodes on quartz crystal microbalance (QCM) were used as working electrodes. A saturated calomel electrode was used as a reference electrode and a platinum wire as counter electrode. $\mathrm{CVs}$ of $\mathrm{Fe}(\mathrm{CN})_{6}{ }^{3-/ 4-}$ were obtained using a solution of $0.1 \mathrm{M} \mathrm{NaClO}_{4}$, containing $1 \mathrm{mM} \mathrm{K}_{3} \mathrm{Fe}(\mathrm{CN})_{6} / \mathrm{K}_{4} \mathrm{Fe}(\mathrm{CN})_{6}$, and scanned at $100 \mathrm{mV} / \mathrm{s}$. EIS were obtained using the same solution with bias potential at open circuit potential, ac amplitude of $10 \mathrm{mV}$, and frequency from $100 \mathrm{kHz}$ to $0.1 \mathrm{~Hz}$. For the CVs of a copper complex, modified electrodes were first immersed in a $5 \mathrm{mM} \mathrm{Cu}\left(\mathrm{ClO}_{4}\right)_{2}$ solution for $1 \mathrm{~h}$, rinsed with biograde water, and placed in a copper-free PBS buffer.

\section{QCM Measurement}

The QCM cell filled with $1 \mathrm{~mL}$ of PBS buffer was placed in a Faraday cage. Contents of the QCM cell were continuously stirred before, during, and after the addition of analyte, which was added to the cell in microliter volumes. A network/spectrum/impedance analyzer (Agilent 4395A) was used to measure the frequency and series damping resistance of the QCM simultaneously.

\section{RESULTS AND DISCUSSION}

\section{ScFv Western Blot}

Anti-E tag affinity purified A10B scFv-Rs, A10B scFv-Cys, A10B scFv-His, and $\mathrm{I} 20 \mathrm{scFv}-$ Rs antibodies were assayed by SDS-PAGE and Western blot to determine scFv integrity. The E-tagged $\mathrm{scFv}$ were detected on blots using peroxidase-conjugated anti-E tag monoclonal antibody. Affinity purified $\mathrm{scFv}$ appeared to be intact and migrated primarily as a single band when analyzed under reducing conditions by gel electrophoresis and Western blot; see Figure 1 .

\section{ScFv ELISA}

Anti-E tag affinity purified A10B scFv-Rs, A10B scFv-Cys, A10B scFv-His, and $\mathrm{I} 20 \mathrm{scFv}-$ Rs were assayed against rabbit IgG, BSA, and CYP1B1 by ELISA. A10B scFv-Rs, A10B $\mathrm{scFv}-\mathrm{Cys}$, and A10B scFv-His were specific and interacted with rabbit IgG positive control antigen in a dose-dependent fashion (Figure 2a) but not with negative control antigens BSA (Figure 2b) or CYP1B1 (Figure 2c). The anti-CYP1B1 I20 scFv-Rs antibody interacted specifically with CYP1B1 in a dose-dependent fashion (Figure 2c) but did not interact with rabbit IgG (Figure 2a) or BSA (Figure 2b). These results demonstrate that A10B scFv-Rs, A10B scFv-Cys, A10B scFv-His, and $\mathrm{I} 20 \mathrm{scFv}-\mathrm{Rs}$ were specific for their corresponding antigens and that linker modifications did not influence $\mathrm{scFv}$ antigen specificity.

\section{Electrochemical Characterization of the Adsorption of A10B scFv-His on Au}

The integrity of the A10B scFv-His modified gold QCM surface was ascertained by exposing the surface to $\mathrm{K}_{4} \mathrm{Fe}(\mathrm{CN})_{6} / \mathrm{K}_{3} \mathrm{Fe}(\mathrm{CN})_{6}$ redox probe using EIS and CV. The resultant Nyquist plot is depicted in Figure 3a. As shown in Figure 3a, the electron-transfer resistance $\left(R_{\mathrm{et}}\right)$ on a bare gold electrode was very low and increased upon subsequent immobilization of A10B scFv-His, blocking with BSA and binding with rabbit IgG. The data demonstrated that a BSAblocked A10B scFv-His gold surface forms an impermeable electron-transfer barrier to electroactive species in an aqueous electrolyte. The same result was also obtained by CVs (Figure $3 b$ ). The presence of the E-tag A10B scFv-His bound to gold surfaces was also confirmed using the peroxidase-conjugated anti-E tag monoclonal antibody and a colorimetric peroxidase substrate (data not shown). 


\section{Adsorption of A10B scFv-His on Au}

To understand how the scFv-His adsorbed on gold, the linker peptides, peptide-H (SHGGHGGGGSGGGGS) and peptide-G ((GGGGS) $)_{3}$ ), were immobilized onto the gold electrode and analyzed. As shown in Figure 4, the increase of the $R_{\mathrm{et}}$ from the EIS results (Figure 4a) and the attenuation of the Faradiac current in the CVs (Figure 4b) were observed only on the electrode treated with peptide- $\mathrm{H}$ solution but not with the peptide-G treated surface. The surface coverage of peptide-H and A10B scFv-His antibody was $6.3 \times 10^{-10}$ and $1.3 \times$ $10^{-10} \mathrm{~mol} / \mathrm{cm}^{2}$, respectively, as calculated from the data depicted in Figure 5. Since the only difference between $\mathrm{scFv}-\mathrm{Rs}$ and $\mathrm{scFv}-\mathrm{His}$ is the two linker peptides, we can conclude that the adsorption is not due to the rest of the amino acids present within the scFv. SPR analysis (data not shown) suggests that the coverage of scFv-His and $\mathrm{scFv}-\mathrm{Rs}$ are similar. However, the higher sensitivity of scFv-His binding with rabbit IgG in comparison to A10B scFv-Rs suggest that $\mathrm{A} 10 \mathrm{~B}$ scFv-His was immobilized correctly on the gold sensor surface and that antigenbinding activity was retained by the His-gold interaction.

Diglycyl-L-histidine (GGH) is a peptide molecule designed to mimic the specific $\mathrm{Cu}^{2+}$ ion transport site of human albumin. ${ }^{20}$ Reports have shown that the GGH bound $\mathrm{Cu}^{2+}$ exclusively as a 1:1 complex in the $\mathrm{pH}$ range of $6.50-11.00$ and had a dissociation constant $1.18 \times 10^{-16}$ M. GGH tripeptide has been used for the electrochemical detection of $\mathrm{Cu}^{2+}$ ions. ${ }^{21} \mathrm{~A} 10 \mathrm{~B}$ $\mathrm{scFv}-\mathrm{His}$ and $\mathrm{A} 10 \mathrm{~B} \mathrm{scFv}-\mathrm{Rs}$ antibodies, peptide-H, and peptide- $\mathrm{G}$ were adsorbed onto gold electrodes. After incubation with $\mathrm{Cu}^{2+}$ in solution, the electrodes were rinsed and then put in $\mathrm{a} \mathrm{Cu}^{2+}$ free electrolyte solution for electrochemical study. Figure 5 depicts $\mathrm{CV}$ s for the abovemodified electrodes. A pair of reversible redox peaks was observed on the peptide-H (Figure $5 \mathrm{a}$ ) and $\mathrm{A} 10 \mathrm{~B} \mathrm{scFv}-\mathrm{His}$ (Figure $5 \mathrm{~b}$ ) modified electrodes but not on peptide-G (Figure 5c) and A10B scFv-Rs (Figure 5d) modified electrodes. For CVs on both scFv-His and peptide-H modified electrodes, the peak currents were proportional to the scan rates (Figure 5e and f), which indicates that the $\mathrm{Cu}^{2+}$ complex was confined on the surface of the electrodes.

Apparently, once a histidine bound to the gold electrode, it would no longer bind to a $\mathrm{Cu}^{2+}$ together with neighboring glycines. Presumably the histidine-gold interaction hindered the free conformational change of the His-Gly units, which were essential for the formation of $\mathrm{GGH}-\mathrm{Cu}^{2+}$ complex. Therefore, the above studies suggest that only one histidine was involved in the adsorption on gold while the other was free to bind to $\mathrm{Cu}^{2+}$ in solute. QCM study of an A10B scFv made with only one histidine at position 124 (A10B scFv-ZnS4, linker sequence is VISNHAGSSRRL) (data not shown) revealed that A10B scFv-ZnS4 adsorbed weakly on gold and bound rabbit IgG poorly. This study further illustrates that the position of histidine within the scFv linker is very important, and it is likely the H121 in scFv-His binds to the gold electrode. Once this histidine residue binds to the gold electrode, it can no longer bind to $\mathrm{Cu}^{2+}$. Therefore, the H124 in scFv-His binds to $\mathrm{Cu}^{2+}$ in 1:1 ratio, as shown in Figure 6 .

Stripping voltammetry is a widely used tool to study surface adsorption. ${ }^{22}$ Figure 7 shows the $\mathrm{CVs}$ of a bare gold electrode in a $\mathrm{KOH}$ solution together with those electrodes pretreated with $\mathrm{scFv}-\mathrm{His}, \mathrm{scFv}-\mathrm{Rs}$, peptide-H, and peptide-G solutions. Reduction peaks were observed for the $\mathrm{CVs}$ on $\mathrm{scFv}-\mathrm{His}$ and peptide- $\mathrm{H}$ treated electrodes. The reduction peaks were absent on scFv-Rs and peptide-G treated electrodes. These results indicate that the histidine, present in both peptide- $\mathrm{H}$ and $\mathrm{A} 10 \mathrm{~B} \mathrm{scFv}-\mathrm{His}$, is responsible for the peptide and $\mathrm{scFv}$ adsorption on gold. 23,24 The reduction peaks vanished gradually in the following cycles, indicating that the reduction products did not interact with gold and thus desorbed from the surface. The surface coverage of peptide- $\mathrm{H}$ and A10B scFv-His is, respectively, $2.2 \times 10^{-10}$ and $6.8 \times 10^{-11} \mathrm{~mol} /$ $\mathrm{cm}^{2}$ as ascertained from stripping voltammograms based on one-electron reduction of histidine (Figure 7). These values are about 2-3 times smaller than those calculated from $\mathrm{Cu}^{2+}$-binding experiments (Figure 5) indicating that the number of charge transfer is less than 1 for the reduction of adsorbed histidine. This rationalization is supported by the work of Zubavichus 
et al. ${ }^{25}$ and Khudyakova et al. ${ }^{26}$ Their study demonstrated that monolayer histidine adsorbed on gold as histidinate anions to form strong ionic-covalent bonds with gold substrate atoms to acquire a partial positive charge. In our system, the $\mathrm{N}_{3}$ atoms of imidazole rings and the hydroxyl group in serine are probably involved in A10B-His binding to the gold substrate.

\section{A10B scFv-His Analyte Detection}

The A10B scFv-His was immobilized on eight identical QCM gold electrodes. Increasing concentrations of rabbit IgG were added to $1 \mathrm{~mL}$ of PBS buffer under stirring. Figure 8a depicts a frequency change versus time curve with respect to changes in rabbit IgG concentration. Data obtained from Figure 8a were used to develop a calibration curve to reflect QCM frequency change versus change in rabbit IgG concentration (Figure 8b). The experimentally and statistically determined detection limit for the A10B scFv-His/rabbit IgG assay was $2.3 \pm 0.15$ $\mathrm{nM}(n=4)$. The linear range is $2.3 \times 10^{-9}-3.3 \times 10^{-8} \mathrm{M}$.

A10B scFv also binds to monomeric rabbit IgG Fab ( $50 \mathrm{kDa})$ fragments that are one-third the size of a whole IgG molecule ( $150 \mathrm{kDa})$. Rabbit Fab fragments were applied to the A10B $\mathrm{scFv}-\mathrm{His}$ modified gold QCM. A change in immunosensor frequency of $32 \mathrm{~Hz}$ was obtained for a $1.4 \times 10^{-7} \mathrm{M}$ rabbit Fab (50 kDa) fragment concentration. When a similar, but not identical, concentration of rabbit $\operatorname{IgG}(150 \mathrm{kDa})$ was passed over the $\mathrm{A} 10 \mathrm{~B} \mathrm{scFv}-\mathrm{His}$ modified gold QCM, a change in immunosensor frequency of nearly $68 \mathrm{~Hz}$ was obtained (Figure 8a). These results suggest that frequency changes stemming from the A10B scFv-His modified gold QCM immunosensor can be readily quantified but are dependent upon antigen molecular weight (e.g. 50000 versus 150 000).

\section{Selectivity of the scFv-His Piezoimmunosensors}

QCM is a mass sensor so any molecule able to bind to the scFv or whole antibody is a potential interference. With a correct orientation, only the paratope (i.e.. the binding site) is exposed to the solution; the nonspecific absorption can be avoided or reduced. A series of negative antigen control experiments were performed to determine antigen specificity of $\mathrm{A} 10 \mathrm{~B} \mathrm{scFv}-\mathrm{His}$ on piezoimmunosensor surfaces. Negative control antigens used were FBS, goat anti-rabbit IgG, goat anti-human IgG, and goat anti-rabbit IgG Fab fragment. For all four negative control antigens, no significant frequency change was observed (Figure 9). These results indicate that little nonspecific adsorption of negative control antigens occurred on the $\mathrm{scFv}-\mathrm{His}$ modified QCM and that the A10B scFv-His QCM immunosensor was antigen specific.

The antigen specificity of A10B scFv-His was compared to A10B scFv-Rs and A10B IgG monoclonal antibody QCM immunosensors. Nonspecific adsorption was detected for monoclonal rabbit IgG and A10B scFv-Rs but not detected for A10B scFv-His modified electrodes, Figure 10a. These QCM immunosensors were also incubated in PBS containing FBS for 7 days to determine scFv piezoimmunosensor stability. After 7 days, and in the absence of a wash step, the frequency change upon exposure to rabbit IgG was measured. Figure 10b shows that the A10B monoclonal IgG and scFv-Rs QCM on immunosensor surfaces lost activity significantly due to biofouling (e.g., the accretion of nonspecific adsorbed contaminants or dissociation from the sensor surface), but the scFv-His QCM immunosensor did not. This study demonstrates that the scFv-His QCM sensor can be used to monitor target antigens after exposure to a "dirty" environment.

\section{Rabbit Serum Analysis}

To further exam the performances of the scFv-His QCM immunosensor in a "real-world" application, we used a rabbit serum sample. The concentration of the rabbit IgG had been previously determined by ELISA to be $9.5 \mathrm{mg} / \mathrm{mL} .{ }^{10}$ This sample was diluted and spiked with known concentrations of rabbit IgG before being measured with the scFv-His QCM 
immunosensor. According to the calibration curve of Figure 8b, the measured frequency change corresponded to an $\operatorname{IgG}$ concentration of $10.7 \pm 1.3 \mathrm{mg} / \mathrm{mL}(n=3)$, which is in reasonably good agreement with the ELISA result.

\section{Rigidity of the Monolayers}

Rigidity of a biofilm is important for quantitative analysis by QCM technique. The Sauerbrey equation (i.e., $\Delta f=-C \Delta m$ ), which relates the frequency change to mass loading, was based on the assumption that the attached film is rigid and strongly coupled to the resonator. A QCM acoustic impedance analysis was used to determine simultaneously the crystal impedance of the resonator for the binding events shown in Figure 8-Figure 10. When impedance was determined in the presence or absence of attached antibodies, changes in the series resistance in the Butterworth-Van Dyke-equivalent circuit ${ }^{27-29}$ were barely detectable. The change of damping resistances in all cases was $\left|\Delta R_{\mathrm{q}}\right| / R_{\mathrm{q}}$ (Table 1). This suggests that the biofilmssimmobilized A10B scFv-His, scFv-Rs, and monoclonal antibodiess-were exhibiting rigid, rather than viscoelastic behavior. Therefore, precise quantitative analysis based on Sauerbrey equation can be achieved.

\section{Kinetic Studies}

The binding between rabbit $\mathrm{IgG}$ and $\mathrm{scFv}-\mathrm{His}$ was described by eq 1. Based on Langmuir adsorption

$$
\begin{array}{r}
{[\text { rabbit- } \mathrm{IgG}]+[\mathrm{scFv}-\mathrm{His}] \underset{k_{\mathrm{off}}}{\stackrel{k_{\mathrm{on}}}{\rightleftharpoons}}} \\
\quad[\text { rabbit-IgG }-\mathrm{scFv} \text { complex }]
\end{array}
$$

isotherm, ${ }^{30}$ association constant $\left(K_{\mathrm{a}}\right)$ and dissociation constant $\left(K_{\mathrm{d}}\right)$ for the binding between rabbit $\mathrm{IgG}$ and $\mathrm{scFv}-\mathrm{His}$ can be evaluated by eq 2 , where $\Delta M_{\max }$ is the maximum binding amount, $\Delta M$ is

$$
\frac{[\text { rabbit }-\mathrm{IgG}]_{0}}{\Delta M}=\frac{[\text { rabbit }-\mathrm{IgG}]_{0}}{\Delta M_{\max }}+\frac{1}{\Delta M_{\max } K_{\mathrm{a}}}
$$

the measured binding amount, and $[\mathrm{rabbit}-\operatorname{IgG}]_{0}$ is the original concentration of rabbit $\operatorname{IgG}$.

Figure 11 shows the plot of [rabbit-IgG $]_{0} / \Delta \mathrm{M}$ versus [rabbit-IgG $]_{0}$ based on the Figure 8 data. According to eq 2, the ratio of the slope to the intercept gives the association constant $\left(K_{\mathrm{a}}\right)$ as $5.2 \times 10^{7} \mathrm{M}^{-1}$, while the reciprocal of the slope gives $\Delta M_{\max }$ as $76.3 \mathrm{ng}$.

[rabbit $-\mathrm{IgG}-\mathrm{scFv}$ complex $]_{\mathrm{t}}=$

$$
[\text { rabbit }-\mathrm{IgG}-\mathrm{scFv} \text { complex }]_{\infty}\left(1-e^{-(-1 / \tau) t}\right)
$$

$$
\begin{aligned}
& \Delta M_{\mathrm{t}}=\Delta M_{\max }\left(1-e^{-(1 / \tau) \mathrm{t}}\right) \\
& \tau^{-1}=k_{\mathrm{on}}[\text { rabbit } \mathrm{IgG}]_{0}+k_{\mathrm{off}}
\end{aligned}
$$

where $\tau$ is the relaxation time of binding, $t$ is time after injection, $k_{\text {on }}$ is the binding kinetics constant, and $k_{\mathrm{off}}$ is the disassociation kinetics constant.

A plot of the reciprocal of the relaxation time of binding $\left(\tau^{-1}\right)$ versus various concentrations of rabbit IgG indicated a linear relationship according to eq 5 (Figure 12). $k_{\text {off }}$, obtained from the intercept, is $3.28 \times 10^{-4} \mathrm{~S}^{-1} ; k_{\text {on }}$, obtained from the slope, is $3.33 \times 10^{4} \mathrm{M}^{-1} \mathrm{~S}^{-1}$. $K_{\mathrm{a}}$, calculated from the ratio of $k_{\mathrm{on}}$ and $k_{\text {off }}$, is $1.0 \times 10^{8} \mathrm{M}^{-1}$; this value is reasonably consistent with the one calculated from the results showed in Figure 11 based on the Langmuir adsorption isotherm $\left(K_{\mathrm{a}}=5.2 \times 10^{7} \mathrm{M}^{-1}\right)$. The linear relationships depicted in Figure 11 and Figure 12 
also support our assumption that a Langmuir model is applicable for the binding of immobilized $\mathrm{scFv}-\mathrm{His}$ and rabbit IgG.

The results measured by QCM matched with data $\left(K_{\text {on }}=5.08 \times 10^{4} \mathrm{M}^{-1} \mathrm{~S}^{-1}, K_{\text {off }}=3.1 \times\right.$ $10^{-3} \mathrm{~S}^{-1}, K_{\mathrm{a}}=1.6 \times 10^{7} \mathrm{M}^{-1}$ ) by our Biacore surface plasmon resonance study for the same system in a reasonable range.

\section{CONCLUSION}

Adsorption of histidine-containing proteins or peptides onto gold surfaces has been reported in the literature. ${ }^{31}$ In the present study, two histidine amino acids were incorporated into the linker peptide of an $\mathrm{scFv}$ recombinant antibody. The histidine-containing scFv specifically adsorbed on Au QCM immunosensor surfaces. The A10B scFv-His on the Au sensor surface was stable, sensitive, and antigen-specific even when used in a highly complex serum sample. The detection limit of the A10B scFv-His immunosensor was $2.3 \pm 0.15 \mathrm{nM}(n=4)$ and had a linear assay range of $2.3 \times 10^{-9}-3.3 \times 10^{-8} \mathrm{M}$. Results obtained from this and an earlier study ${ }^{10}$ suggest that the scFv linker region, modified to contain either histidines or cysteines, can be used to covalently tether scFv antibody to Au. Recombinant scFv antibodies immobilized and correctly oriented onto Au QCM immunosensors by linker histidines and cysteines are stable and can be successfully used to specifically detect trace amounts of antigen in complex biological samples. Immunoassays utilizing Au QCM immunosensors that incorporate properly oriented $\mathrm{scFv}$ are more sensitive and do not experience the background problems encountered when traditional IgG antibodies or improperly oriented scFv are used as part of a QCM immunoassay platform. At present, seven different $\mathrm{scFv}$ recombinant antibodies specific for either a levuglandin (an isoketal that forms a protein adduct), prostaglandin $\mathrm{E}_{2}$, CYP1B1 (a P450 enzyme), or p-selectin have been modified to contain either cysteines or histidines within the linker $\mathrm{scFv}$ region. Either histidine or cysteine linker modification for some, but not all scFv antibodies influenced antigen-binding activity or bacterial protein expression (data not presented here). However, in nearly every case, scFv antigen-binding activity compromised when one of the two amino acids (histidine or cysteine) were used to modify the linker could be retained when the other amino acid was used. Based on these preliminary observations, and in order for the potential of scFv based-Au QCM immunosensors to be fully realized, it will be important to determine whether these amino acids can be located in the linker region of most scFv antibodies or if other sites within or on the amino or carboxyl terminus of the scFv work as well or better and are more suited for use on Au QCM surfaces.

\section{ACKNOWLEDGMENT}

This research was supported by NIH (1R21EB000672-01, 4R33EB000672-02, 5P30 CA68485-07, 5P30 ES00267-36). We thank Julie Brown from the Vanderbilt University Molecular Recognition and Screening Facility for purifying scFv DNA used for sequencing and proteins used for immunoassays described in the present study. X.Z. is thankful for the support from Oakland University, Chemistry Department.

\section{References}

1. Rogers KR. Mol. Biotechnol 2000;14:109-129. [PubMed: 10872504]

2. Rogers, KR.; Mulchandani, A. Affinity Biosensors. Vol. 7: Techniques and Protocols. Totowa, NJ: Humana Press Inc.; 1998.

3. Vijayendran RA, Leckband DE. Anal. Chem 2001;73:471-480. [PubMed: 11217749]

4. Davis KA, Leary TR. Anal. Chem 1989;61:1227-1230. [PubMed: 2757206] (b) Vikholm I, Albers WM. Langmuir 1998;14:3865-3872.

5. Kroger D, Liley M, Schiweck W, Skerra A, Vogel H. Biosens. Bioelectron 1999;14:155-161. [PubMed: 10101837] 
6. Bird RE, Hardman KD, Jacobson JW, Johnson S, Kaufman BM, Lee SM, Lee T, Pope SH, Riordan GS, Whitlow M. Science 1988;242:423-426. [PubMed: 3140379]

7. Huston JS, Levinson D, Mudgett-Hunter M, Tai MS, Novotny J, Margolies MN, Ridge RJ, Bruccoleri RE, Haber E, Crea R. Proc. Natl. Acad. Sci. U.S.A 1988;85:5879-5883. [PubMed: 3045807]

8. Padlan EA. Mol. Immunol 1994;31:169-217. [PubMed: 8114766]

9. Hudson PJ. Curr. Opin. Biotechnol 1998;9:395-402. [PubMed: 9720265]

10. Shen Z, Stryker G, Mernaugh R, Yu L, Zeng X. Anal. Chem 2005;77:797-805. [PubMed: 15679346]

11. Kroger D, Liley M, Schiweck W, Skerra A, Vogel H. Biosens. Bioelectron 1999;14:155-161. [PubMed: 10101837]

12. Ferapontova EE, Grigorenko VG, Egorov AM, Boerchers T, Ruzgas T, Gorton L. J. Electroanal. Chem 2001;509:19-26.

13. Zou J, Taylor P, Dornan J, Robinson SP, Walkinshaw MD, Sadler PJ. Angew. Chem., Int. Ed 2000;39:2931-2934.

14. Djalali R, Chem Y, Matsui H. J. Am. Chem. Soc 2002;124:13660-13661. [PubMed: 12431080]

15. Slocik JM, Moore JT, Wright DW. Nano Lett 2002;2:169-173.

16. Collins JA, Xirouchaki C, Palmer RE, Heath JK, Jones CH. Appl. Surf. Sci 2004;22:197-208.

17. Lipkowski, J.; Stolberg, L. Adsorption of Molecules at Metal Electrodes. Lipkowski, J.; Ross, PN., editors. New York: VCH; 1992.

18. Yang W, Jaramillo D, Gooding JJ, Hibbert DB, Zhang R, Willett GD, Fisher KJ. Chem. Commun 2001:1982-1983.

19. Zhang Y, Pool C, Sadler K, Yan HP, Edl J, Wang X, Boyd JG, Tam JP. Biochemistry 2004;43(39): 12575-12584. [PubMed: 15449947]

20. Show JL, Kruck PA, Sarkar B. J. Biol. Chem 1974;249:5878-5884. [PubMed: 4411707]

21. (a) Yang WR, Hibbert DB, Zhang R, Willett GD, Gooding JJ. Langmuir 2005;21:260-265. [PubMed: 15620312] (b) Yang WR, Chow E, Willett GD, Hibbert DB, Gooding JJ. Analyst 2003;128:712718. [PubMed: 12866893]

22. Skoog, DA.; West, DM.; Holler, FJ.; Crouch, SR. Fundamentals of Analytical Chemistry. 8th ed. Belmont CA: Thomson-Brooks/Cole; 2004.

23. Van Paemel C, Frumin H, Brooks VL, Failor R, Sevilla MD. J Phys. Chem 1975;79:839-845.

24. Sevilla MD, Brooks L. J. Phys. Chem 1973;77:2954-2959.

25. Zubavichus Y, Zharnikov M, Yang Y, Fuchs O, Heske C, Umbach E, Tzvetkov G, Netzer FP, Grunze M. J. Phys. Chem. B 2005;109:884-891. [PubMed: 16866455]

26. Khudyakova RV, Soloshko SVA, Safronov Y. Elektrochimiya 1997;33:1165.

27. Ngeh-Ngwainbi J, Suleiman AA, Guilbault GG. Bioelectronics 1990;5:13-26.

28. Schmitt N, Tessier L, Watier H, Patat F. Sens. Actuators, B 1997;43:217-223.

29. Su X, Chew F, Li S. Anal. Biochem 1999;273:66-72. [PubMed: 10452800]

30. (a) Ebara Y, Itakura K, Okahata Y. Langmuir 1996;12:5165-5170. (b) Okahata Y, Natsuura K, Ito K, Ebara Y. Langmuir 1996;12:1023-1026. (c) Yang M, Yau HCM, Chan HL. Langmuir 1998;14:6121-6129.

31. Slojkowska R, Jurkiewicz-Herbich M. Colloids Surf., A 2001;178:325-336. 


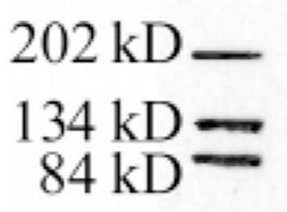

$40 \mathrm{kD}-$

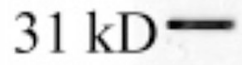

$17 \mathrm{kD}-$

$7 \mathrm{kD}-$

\section{$\begin{array}{llll}M W & A 10 B & A 10 B & \text { I20 }\end{array}$ Markers ScFv-Rs ScFv-Cys ScFv-Rs ScFv-His}

Figure 1.

Western blot for E-tagged affinity purified scFv: A10B scFv-Rs, A10B scFv-Cys, I20 scFv$\mathrm{Rs}$, and $\mathrm{A} 10 \mathrm{~B}$ scFv-His. Affinity purified E-tagged scFv were probed with the anti-E tag monoclonal antibody conjugated to peroxidase. Intact recombinant $\mathrm{scFv}$ migrate primarily as a single band at a molecular weight of $\sim 30000$. 

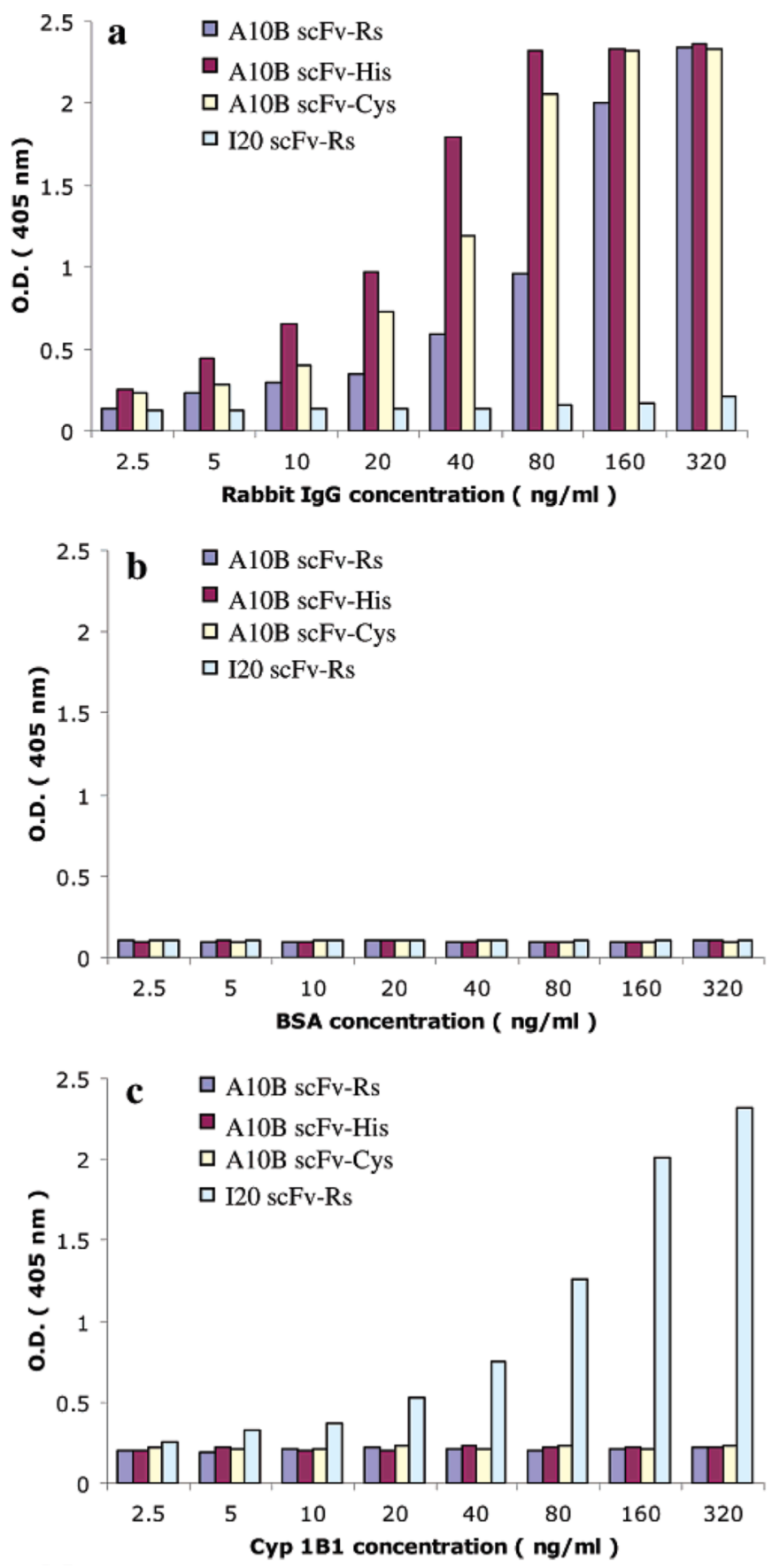

Figure 2.

ELISA results for A10B scFv-Rs (blue), A10B scFv-His (wine), A10B scFv-Cys (yellow), and I20 scFv-Rs (cyan) on microtiter wells coated with rabbit IgG (a), BSA (b), or CYP1B1 (c). 

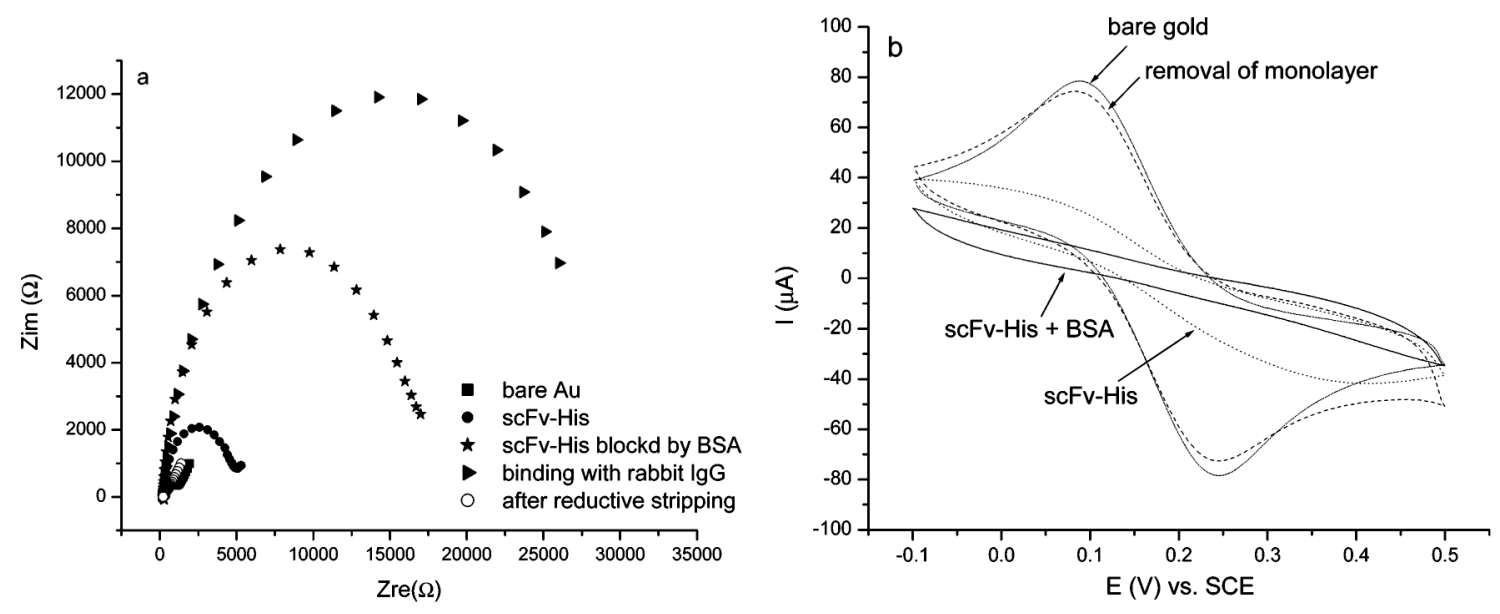

Figure 3.

(a) Nyquist plots of EIS in $1 \mathrm{mM} \mathrm{Fe}(\mathrm{CN})_{6}{ }^{3-/ 4-} / 0.1 \mathrm{M} \mathrm{NaClO}_{4}$ solution when the gold electrode was bare, modified by scFv-His, BSA, IgG, and recovered later. (b) CVs in same solution on bare, scFv-His modified, scFv-His/BSA modified, and recovered bare gold electrode. Scan rate, $100 \mathrm{mV} / \mathrm{s}$. 

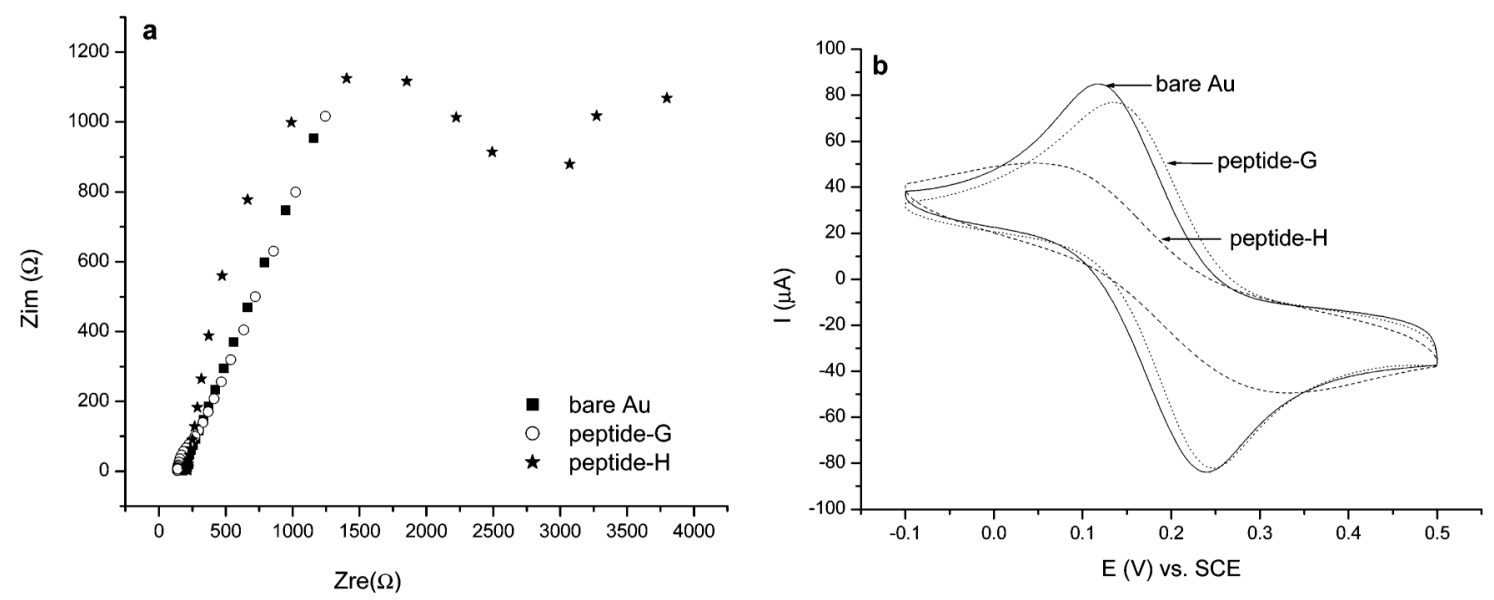

Figure 4.

(a) Nyquist plots and (b) $\mathrm{CVs}$ of $1 \mathrm{mM} \mathrm{K}_{4} \mathrm{Fe}(\mathrm{CN})_{6} / \mathrm{K}_{3} \mathrm{Fe}(\mathrm{CN})_{6}$ in $0.1 \mathrm{M} \mathrm{NaClO}_{4}$ solution on bare, peptide-H modified, and peptide- $\mathrm{G}$ modified gold electrodes. 

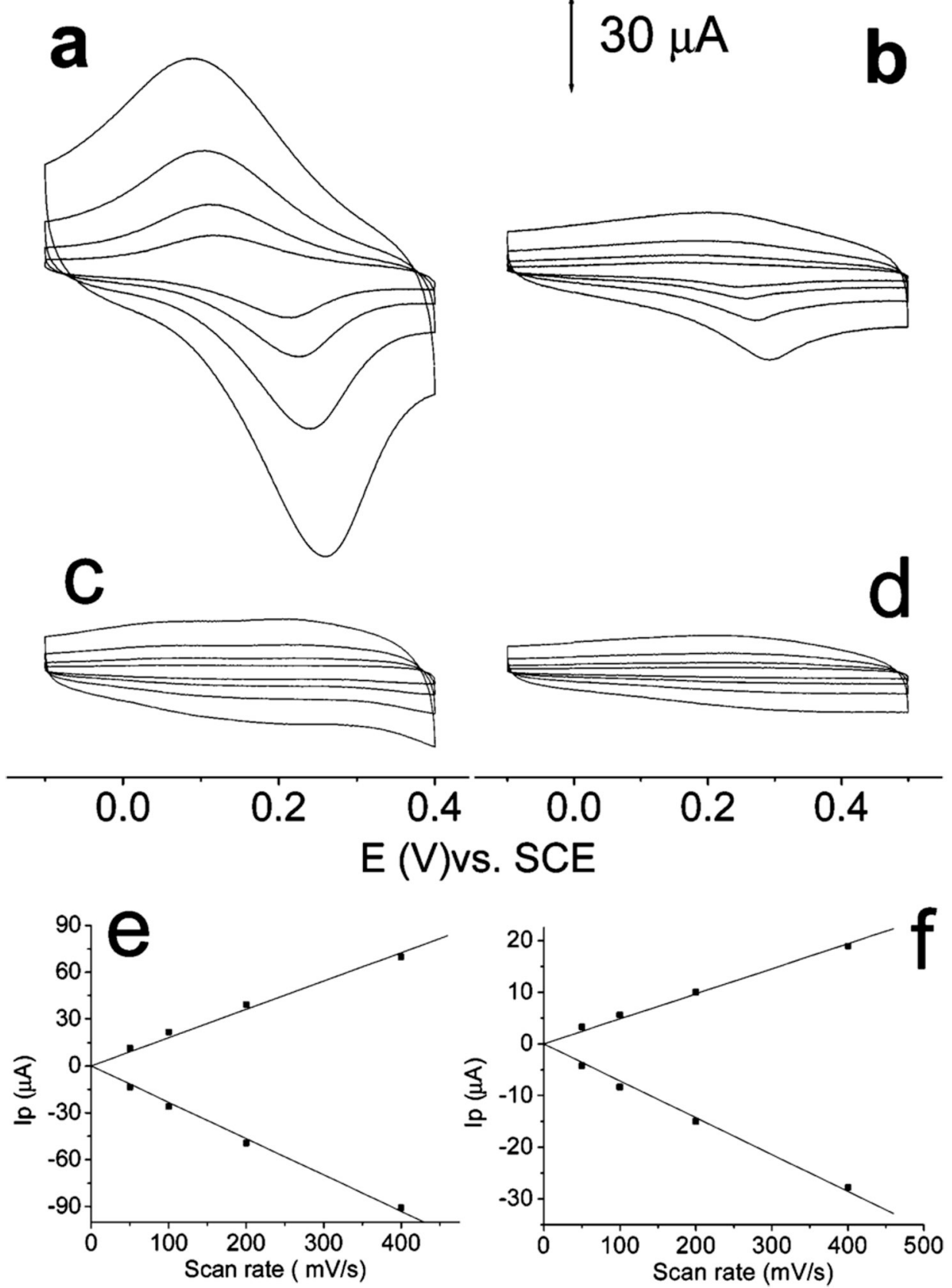

Figure 5.

CVs of (a) peptide-H modified electrode, (b) scFv-His modified electrode, (c) peptide-G modified electrode, and (d) scFv-Rs modified electrode in PBS buffer ( $\mathrm{pH}$ 7.2). Scan rate: 50, 100,200 , and $400 \mathrm{mV} / \mathrm{s}$ in $(\mathrm{a}-\mathrm{d})$, respectively. The electrodes were pretreated in a $5 \mathrm{mM}$ $\mathrm{Cu}^{2+}$ solution. Peak currents vs scan rates on (e) peptide-H modified electrode and (f) $\mathrm{scFv}-$ His modified electrode. 


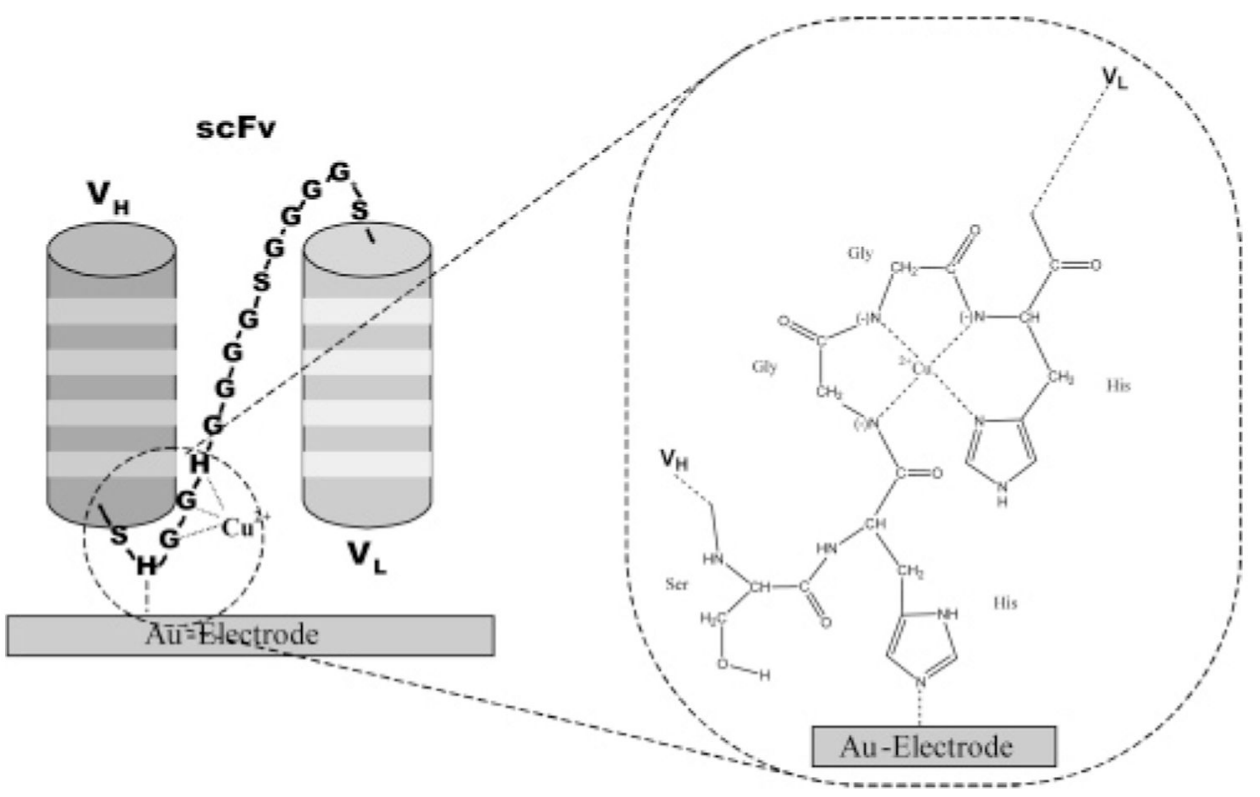

Figure 6.

Schematic diagram of A10B scFv-His adsorption and $\mathrm{Cu}^{2+}$ incorporation on a Au electrode. 


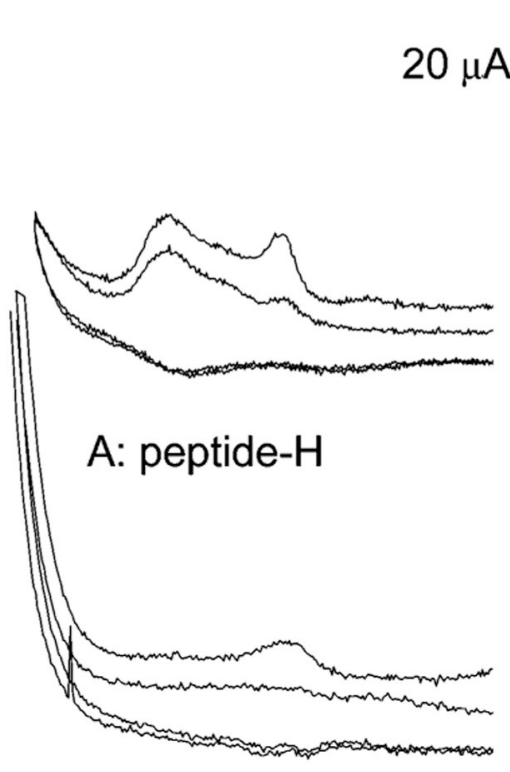

B: scFv-His

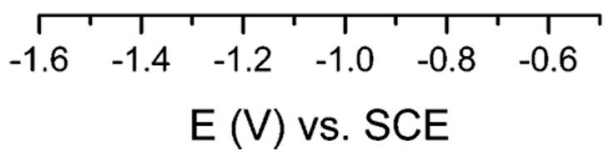

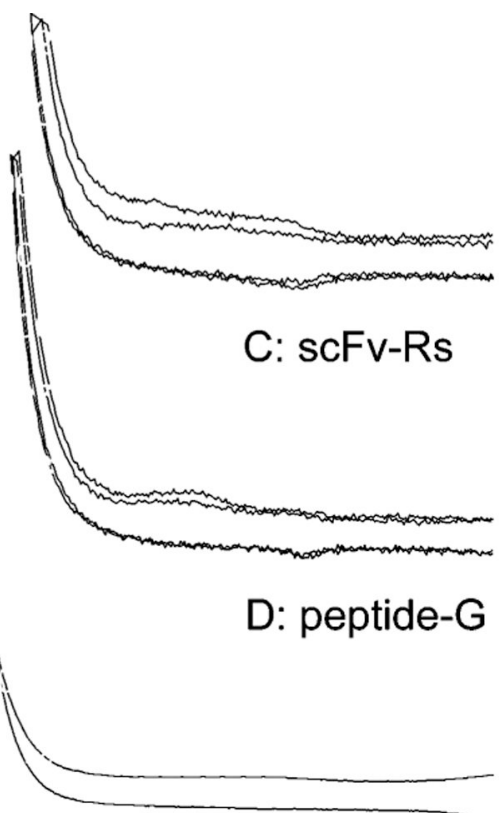

$\mathrm{E}$ : bare Au

Figure 7.

CVs of (A) peptide-H modified gold electrode, $(\mathrm{B}) \mathrm{scFv}-\mathrm{His}$ modified gold electrode, (C) scFv-Rs modified gold electrode, (D) peptide-G modified gold electrode, and (E) bare gold electrode in $0.5 \mathrm{M} \mathrm{KOH}$ solution at a $100 \mathrm{mV} / \mathrm{s}$ scan rate. 

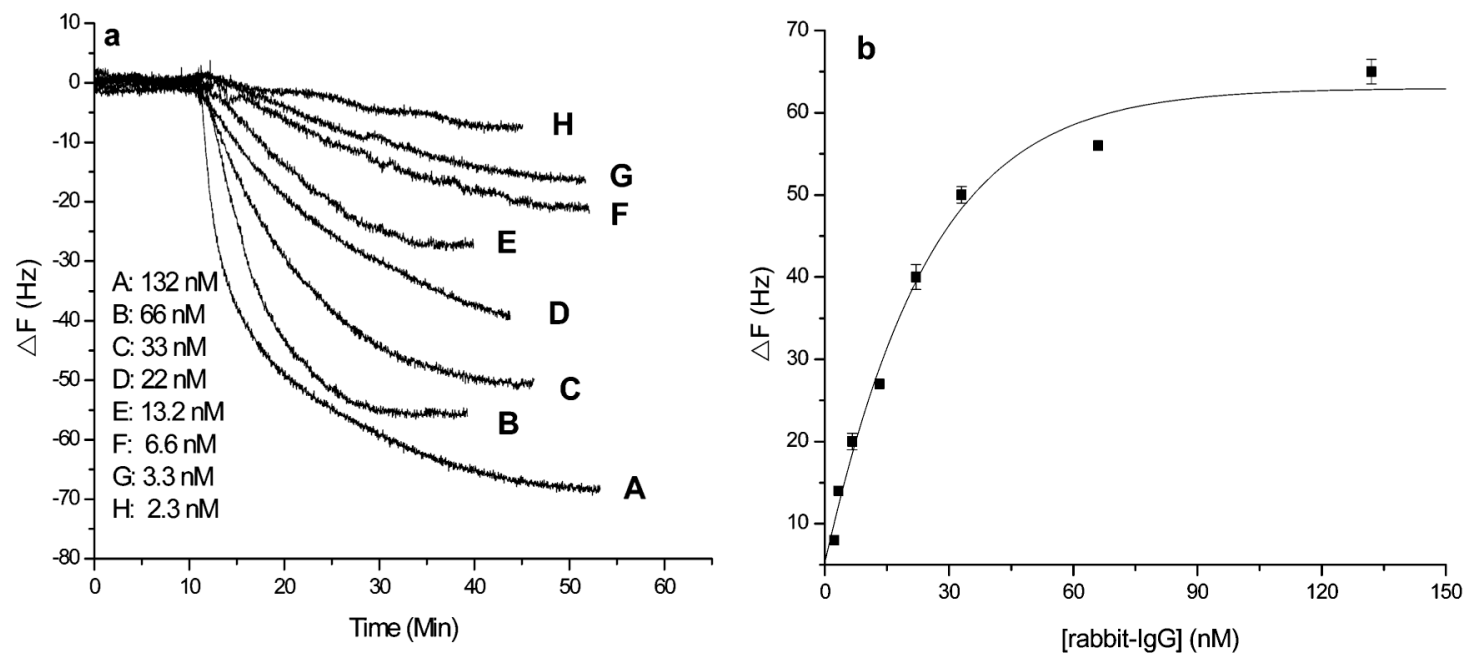

Figure 8.

(a) Frequency change vs time when $20-\mu \mathrm{L}$ volumes of rabbit $\mathrm{IgG}$, at varying concentrations, was added to the 1-mL PBS stirred scFv-His modified Au QCM reaction chamber. (b) Frequency change vs rabbit IgG concentration on A10B scFv-His QCM surface. Final concentrations of rabbit IgG ranged from $2.3 \times 10^{-9}$ to $1.32 \times 10^{-7} \mathrm{M}$. 


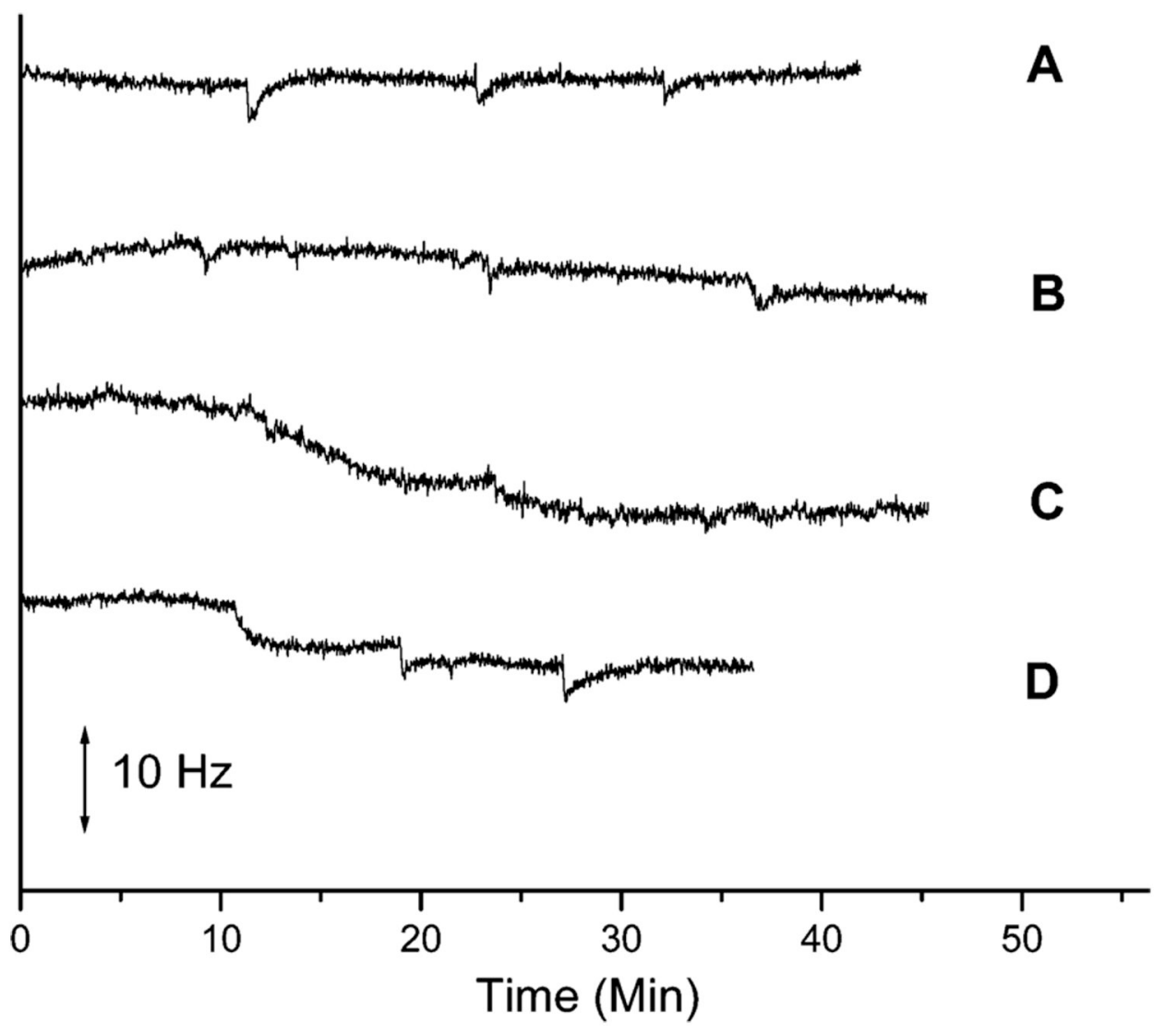

Figure 9.

Frequency change vs time curves obtained in $21.6 \mu \mathrm{g} / \mathrm{mL}$ FBS (curve A), $3.96 \times 10^{-7} \mathrm{M}$ goat anti-rabbit IgG (curve B), $3.96 \times 10^{-7} \mathrm{M}$ goat anti-human $\operatorname{IgG}$ (curve C), and $2.77 \times 10^{-7} \mathrm{M}$ goat anti-rabbit IgG Fab (curve D) PBS buffer solutions on an A10B scFv-His Au QCM cell. 


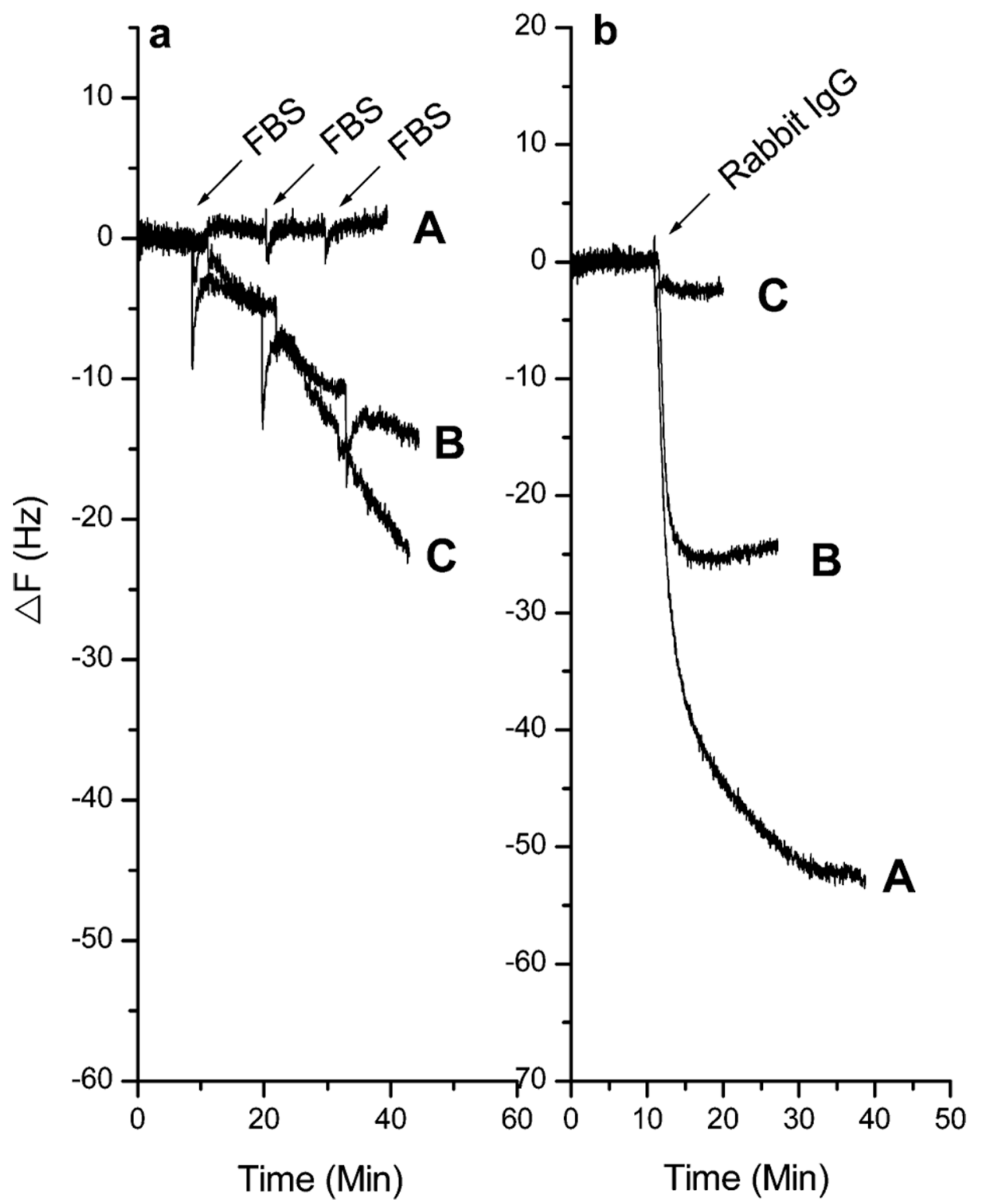

Figure 10.

Frequency changes vs time curves for A10B scFv-His (curve A), IgG monoclonal antibody (curve B), and A10B scFv-Rs (curve C) QCM immunosensor exposure to (a) $21.6 \mu \mathrm{g} / \mathrm{mL}$ FBS and (b) $1.32 \times 10^{-7} \mathrm{M}$ rabbit IgG after immunosensors were incubated in FBS for 7 days. 


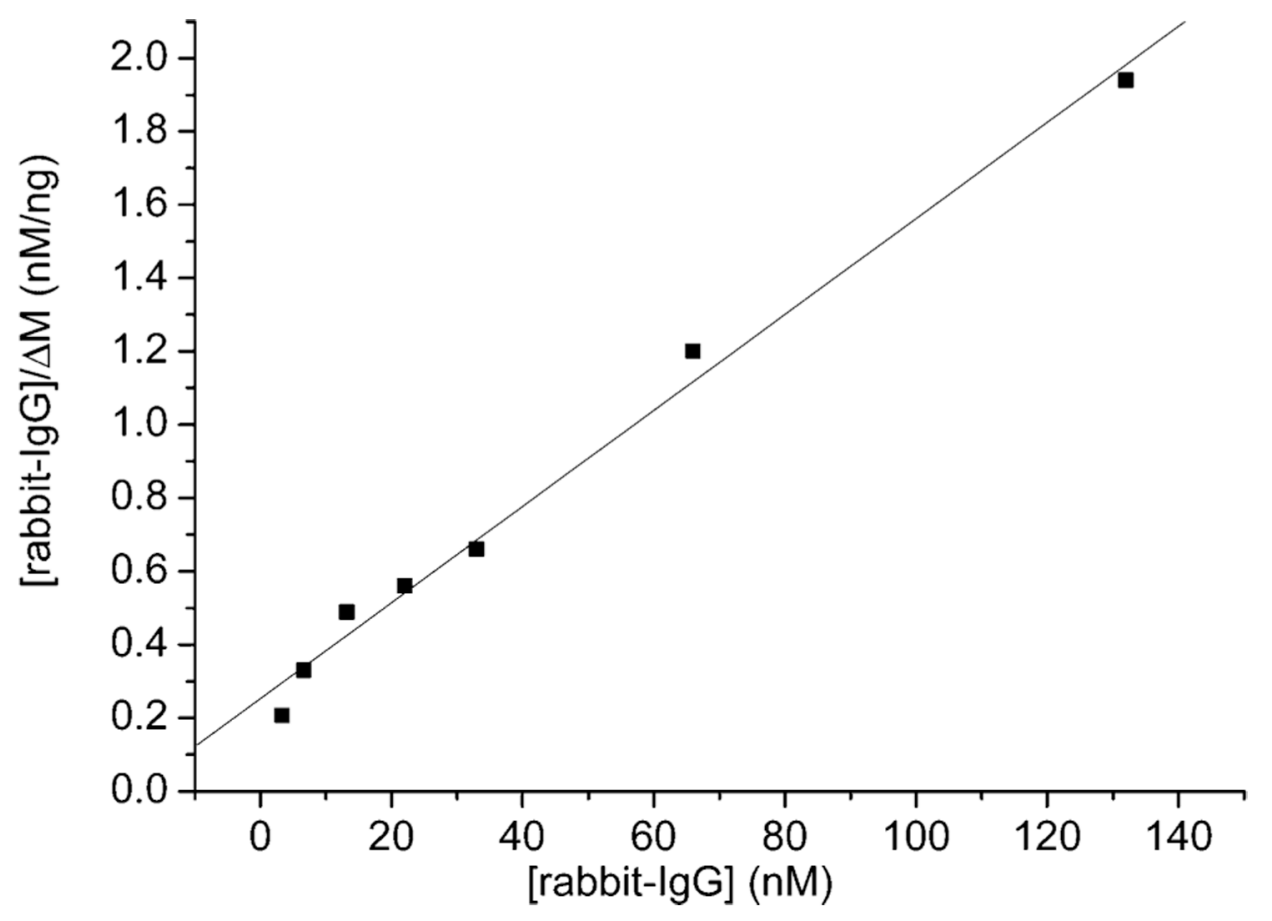

Figure 11.

$[\text { rabbit-IgG }]_{0} / \Delta \mathrm{M}$ vs $[\text { rabbit-IgG }]_{0}$ of rabbit IgG binding with scFv. 


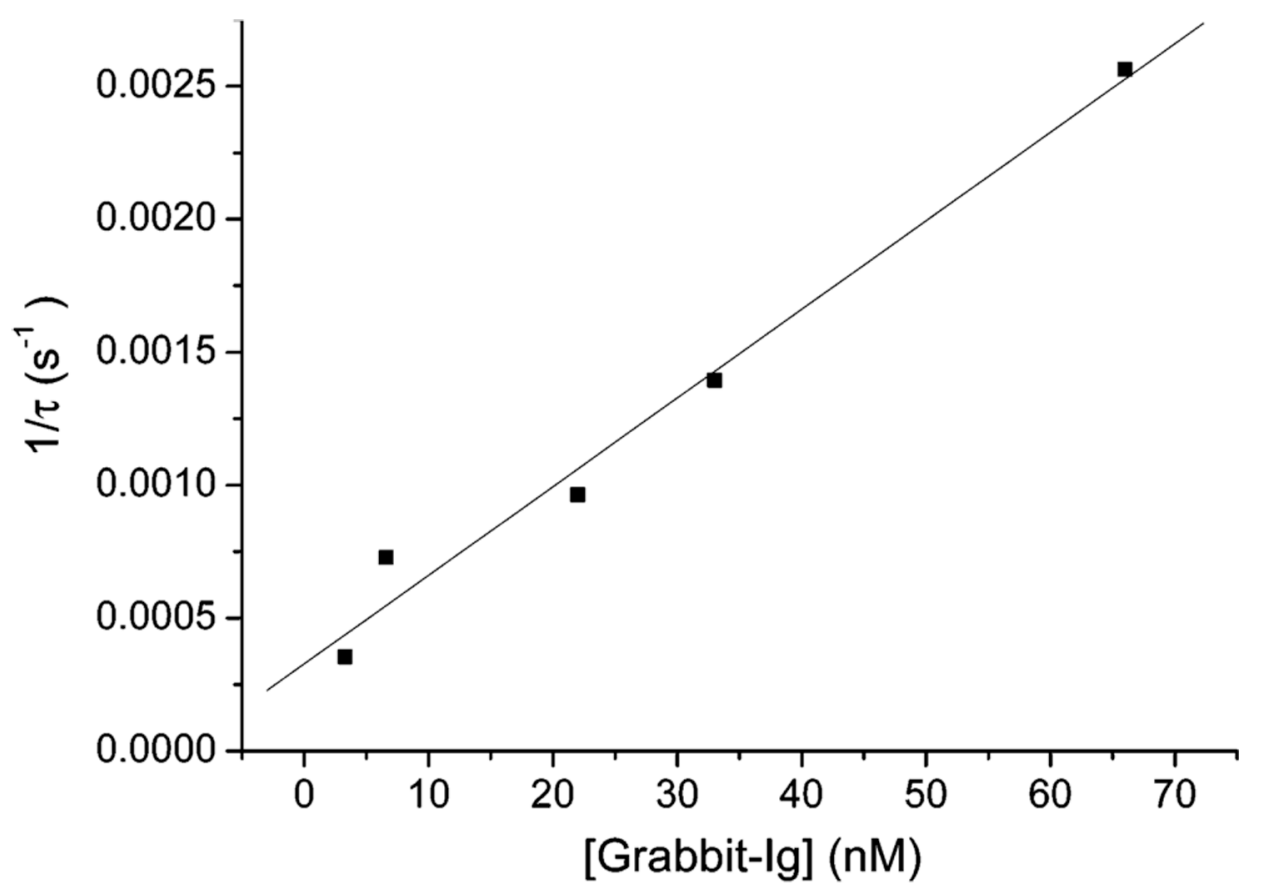

Figure 12.

$1 / \tau$ vs [rabbit-IgG] of rabbit IgG binding with scFv. 
Table 1

Changes (\%) in Damping Resistances for Experiments Shown in Figure 9-Figure $11^{a}$

\begin{tabular}{|c|c|c|c|}
\hline Figure 8a & $\left|\Delta R_{\mathrm{q}}\right| / R_{\mathrm{q}}$ & Figure 10a & $\left|\Delta R_{\mathrm{q}}\right| / R_{\mathrm{q}}$ \\
\hline A & 1.1 & A & 0.4 \\
\hline B & 0.8 & B & 0.1 \\
\hline $\mathrm{C}$ & 1.1 & $\mathrm{C}$ & 0.1 \\
\hline D & 0.1 & Figure $10 b$ & $\left|\Delta R_{\mathrm{q}}\right| / R_{\mathrm{q}}$ \\
\hline E & 0.6 & A & 0.8 \\
\hline $\mathrm{F}$ & 0.4 & B & 0.2 \\
\hline $\mathrm{G}$ & 0.06 & $\mathrm{C}$ & 0.1 \\
\hline $\mathrm{H}$ & 0.2 & & \\
\hline Figure 9 & $\left|\Delta R_{\mathrm{q}}\right| / R_{\mathrm{q}}$ & & \\
\hline A & 0.4 & & \\
\hline B & 0.4 & & \\
\hline $\mathrm{C}$ & 0.6 & & \\
\hline D & 0.2 & & \\
\hline
\end{tabular}

${ }^{a}$ The relationship of the amount of rabbit $\mathrm{IgG}-\mathrm{scFv}$ complex formed with time after injection was shown in eq 3-5. 